\title{
What Does Pakistan Have to Join the Inflation Targeters' Club-a Royal Flush or a Seven-Deuce Offsuit?
}

\author{
Syed Kumail Abbas Rizvi", Bushra Naqvi**, Sayyid Salman \\ Rizavi $^{* * *}$
}

\begin{abstract}
The economic and institutional structure required to successfully adopt and implement an inflation targeting framework (ITF) is often lacking in emerging economies. This paper evaluates these structures both qualitatively and quantitatively for Pakistan's economy. Although our comprehensive assessment finds that many of the core requirements remain unrealized, the literature and real-time experience argue that an ITF remains possible for emerging economies even in the absence of these conditions. We investigate whether-were the State Bank of Pakistan to adopt an ITF-there exists a stable and significant relationship between the policy rate (monetary tool) and inflation measure (objective). It is important to analyze this bivariate relationship, given the key role of the interest rate in mitigating deviations between actual and target inflation when working within an ITF. To illustrate this relationship, we use Granger Causality test, but our estimates fail to find any significant link between the interest rate and inflation. On the basis of our overall findings, we suggest that Pakistan, in the absence of most of the fundamental requirements of an ITF, is perhaps not yet ready for it.
\end{abstract}

Keywords: Inflation targeting, Pakistan, monetary policy.

JEL Classification: E30, E52, E58.

\section{Introduction}

Over the last two decades, a monetary policy framework that has gained global recognition is the inflation targeting framework (ITF). There is a growing literature on its applicability, its effects on economic performance, and its superiority over other frameworks (exchange rate targeting, monetary aggregate targeting, etc.). Inflation targeting has been

\footnotetext{
* Assistant Professor, Lahore School of Economics, Pakistan.

** Assistant Professor, Suleman Dawood School of Business, Lahore University of Management Sciences, Pakistan.

*** Assistant Professor, Hailey College of Commerce, University of the Punjab, Pakistan.
} 
defined as a framework for monetary policy in which central banks commit to low and stable inflation as their long-term objective, publicly announce quantitative targets, and hold themselves accountable to achieving these targets (Bernanke, Laubach, Mishkin, and Posen, 1999).

The literature attributes three reasons to the widespread adoption of ITFs: First, the only macroeconomic variable that monetary policy is capable of affecting in the long run is the inflation rate. Second, there is virtual consensus on the negative impacts of even modest inflation on economic efficiency and growth. Although, the link between inflation and overall economic performance is ambiguous in theory as inflation is determined by the interaction of many factors, a significant number of econometric studies associate high inflation with low productivity and with a low rate of growth (Fischer, 1993; Judson \& Orphanides, 1996; Bruno \& Easterly, 1998). Third, inflation targeting works as a "nominal anchor" by imposing several constraints on central banks.

The successful adoption and implementation of an ITF strongly requires the existence of certain "economic" and "institutional" prerequisites in the candidate country. When it comes to emerging and developing economies, however, these prerequisites often do not exist (Masson, Savastano, \& Sharma, 1997). These include: the independence of the central bank, transparency of information, fiscal discipline, a floating exchange rate, moderate or low debt levels, sufficient foreign reserves, demand-side dominance, and the strength of the financial system (Masson et al., 1997; Bernanke et al., 1999; Mishkin, 2000; Taylor, 2000).

In this study, we evaluate these prerequisites both qualitatively and quantitatively to assess the applicability of an ITF to Pakistan. Assuming the State Bank of Pakistan (SBP) were to adopt an ITF as its main monetary policy framework, we also examine whether there exists a stable and significant relationship between the interest rate (proxied by the policy rate or PR), which is the principal monetary policy tool used to affect inflation in inflation targeting countries, and inflation (proxied by the consumer price index or CPI). To illustrate this bivariate relationship, we use a Granger causality test through which we determine the authenticity of causality running from the PR to inflation (PR Granger-cause inflation). This gives us an idea of whether the PR is able to affect inflation, its behavior, and dynamics to the same extent as required by an ITF to mitigate the deviations between actual and target inflation in the short run. 
Our assessment of prerequisites reveals that Pakistan either fails to meet most of the preconditions of inflation targeting or only partially meets them. In addition, as far as the relationship between the interest rate and inflation measure is concerned, our results indicate that the PR does not Granger-cause inflation, which means that the interest rate does not seem to affect inflation directly and thus cannot be used to forecast inflation dynamics.

The remainder of this paper is organized as follow: Section 2 provides an overview of monetary policy developments in Pakistan and the main objectives of its monetary policy. Section 3 discusses the prerequisites for adopting an ITF, and broadly assesses whether Pakistan meets those requirements. Section 4 develops an econometric framework to determine the viability of an ITF in Pakistan by estimating the relationships between the inflation measure, short-term interest rate, and other policy anchors. Section 5 concludes the paper.

\section{Monetary Policy Developments in Pakistan}

In the late 1980s, the monetary authorities in Pakistan started working on 'comprehensive financial sector reforms' with the help of the International Monetary Fund (IMF) and the World Bank. Many steps have been taken since then, but two key measures were the turning point for the monetary sector.

i. The first was the statutory independence of the central bank, which took place in 1994 when the SBP was assigned sole responsibility for making and implementing monetary policy.

ii. The second important step was the adoption of market-based or indirect instruments of monetary policy. Before this, the SBP had relied on an administered monetary policy regime governed by ad hoc changes in the reserve ratio, directed credit, and regulated interest rate policies.

From the onslaught of financial sector reforms in Pakistan during the 1980s and the initiation of the bank's independence in 1993, the SBP started to follow monetary aggregate targeting in 1994 on a de jure basis, assuming a stable demand for the money function in Pakistan. The ultimate goals of monetary policy under the framework of monetary aggregate targeting were inflation reduction (maintaining price stability) and output growth with broad money (M2) as the intermediate target and 
base money or reserve money as the operational target. Moreover, with the adoption of market-based instruments, more attention was paid to managing the short-term interest rate; and the SBP adopted a three-day SBP discount rate as the major policy instrument with which to signal the easing or tightening of monetary policy.

On a de facto basis, although the SBP has been found to pursue the ultimate objective of high GDP growth and low inflation-as confirmed by the objective function developed by Malik (2007), but in line with the assessment of the IMF (2006), which has classified Pakistan's monetary regime as a "hybrid" regime-Malik (2007) argues that the country's policy has focused on several other factors such as the foreign interest rate, exchange rate, and trade deficit. Moreover, monetary policy in Pakistan can be characterized by "discretion and judgment" rather than as being "model- or rule-based," which brings about the problem of time inconsistency (see Barro \& Gordon, 1983; Kydland \& Prescott, 1977). It is worth noting that, though the SBP follows monetary aggregate targeting, there is no information available on the underlying macroeconomic model it uses. The SBP only announces its short-term targets for the period of one year, and there are no model-based projections given for the medium term. Geraats (2005) argues that short-term targets are indeed forecasts rather than targets in the real sense because monetary policy affects inflation with lags greater than one year.

\section{Infrastructure for the Adoption of Inflation Targeting in Pakistan}

The discretion- and judgment-based actions that currently characterize Pakistan's monetary regime also typified the dilemma that led to the popularity of the ITF in the rest of the world. Inflation targeting is not a pure "rule"; rather, it is a framework for policy within which "constrained discretion" can be exercised (Bernanke et al., 1999). This discretion is constrained by the announcement and commitment of a central bank to pursue low stable inflation as its ultimate objective.

Beginning with New Zealand, many developed and emerging economies have adopted ITFs, and their experience has been generally positive. However, it is often argued that economic structures in emerging economies are incapable of supporting an IT regime in the short and medium run. Ample research has been conducted to identify whether an ITF could be an appropriate framework for these economies despite the absence of its prerequisites, and the answer appears to be affirmative (Masson, Savastano, \& Sharma, 1998). 


\subsection{Prerequisites}

The literature defines varying prerequisites for an ITF. In Table 1, we provide a consensus-based list of these prerequisites (Bernanke et al., 1999; Masson et al., 1997; Mishkin, 2000; Taylor, 2000).

Table 1: Prerequisites for ITF

\begin{tabular}{ll}
\hline Prerequisite & \multicolumn{1}{c}{ Rationale } \\
\hline $\begin{array}{l}\text { Independence of } \\
\text { central bank }\end{array}$ & $\begin{array}{l}\text { Independence is important to make the policy credible and } \\
\text { to make responsibilities and accountability clear. }\end{array}$ \\
$\begin{array}{l}\text { Transparency of } \\
\text { information }\end{array}$ & $\begin{array}{l}\text { The central bank ought to communicate clearly and } \\
\text { frequently with the government, markets, and the public in } \\
\text { order to earn credibility. This condition is often referred to } \\
\text { as the transparency objective. }\end{array}$ \\
Fiscal discipline & $\begin{array}{l}\text { Fiscal policy must be compatible with monetary policy, the } \\
\text { conduct of which should not be constrained by the fiscal } \\
\text { deficit. This requires that fiscal deficits be reduced through } \\
\text { revenue-based measures rather than by relying on the } \\
\text { central bank for domestic borrowing (Masson et al., 1997). }\end{array}$ \\
High fiscal deficits also lead to high inflationary pressures \\
in the economy.
\end{tabular}

\subsection{Does Pakistan Meet ITF Prerequisites?}

In the following sections, we evaluate the Pakistani economy against the prerequisites listed above. 


\subsubsection{Independence of Central Bank}

The empirical justification for central bank autonomy is based on studies demonstrating that there is a robust negative correlation between central bank autonomy and inflation. The State Bank of Pakistan Act 1956 with subsequent amendments describes the current functions and responsibilities of the SBP as the central bank of Pakistan. Two amendments are worth noting with reference to the SBP's autonomy.

- A bill ${ }^{1}$ was passed in February 1994 that established the SBP's formal and legal autonomy by making monetary policy its sole responsibility.

- An amendment was approved in January 1997 that further enhanced the SBP's independence by giving it the right to determine and enforce limits on government borrowing from it.

However, an ordinance in 2000 compromised the SBP's effective autonomy in two ways. First, it authorized the federal government to direct the SBP to set up funds for special purposes (credit schemes); second, it delegated authority to the President to appoint the governor of the SBP, making the bank vulnerable to political pressures (Malik \& Din, 2008).

Although the 2000 ordinance weakened the SBP's independence, this was countered in 2005 by the Fiscal Responsibility and Debt Limitation Act 2005, which required the government to reduce its revenue deficit to zero by 30 June 2008 and maintain it thereafter, and to concurrently reduce public debt to 60 percent of GDP by 2013 and below that limit thereafter. However, there were serious flaws in its implementation, which were pointed out by Shamshad Akhtar, the governor of the SBP, who said that, "the government had borrowed 204 billion rupees between January and March and 283.9 billion from April to June (2008). In the last two days alone, it borrowed 55 billion rupees."

A recent IMF working paper by Arnone, Laurens, Segalotto, and Sommer (2007) calculates the autonomy of the central banks of 163 countries at the end of 2003. The comparative results with reference to Pakistan are reported in Table 2 below.

\footnotetext{
${ }^{1}$ Act II of 1994, S.2 and S.3.
} 
Table 2: Central banks' comparative autonomy

\begin{tabular}{lccc}
\hline \multicolumn{1}{c}{ Economy } & $\begin{array}{c}\text { Political } \\
\text { autonomy }\end{array}$ & $\begin{array}{c}\text { Economic } \\
\text { autonomy }\end{array}$ & $\begin{array}{c}\text { Overall } \\
\text { autonomy }\end{array}$ \\
\hline Pakistan & 0.38 & 0.63 & 0.50 \\
India & 0.25 & 0.75 & 0.50 \\
Average for EMEs & 0.56 & 0.75 & 0.65 \\
Average for advanced economies & 0.70 & 0.81 & 0.75 \\
\hline
\end{tabular}

Source: Arnone, Laurens, Segalotto, and Sommer (2007).

Arnone et al. (2007) and the recent facts mentioned above suggest that the SBP is far less politically independent when compared to emerging and developed economies not only overall but also individually, both in the political and economic domains.

\subsubsection{Transparency of Information}

Transparency is another important ITF prerequisite and a byproduct of central bank independence. Over time, the importance of transparency has increased due to its impact on expectations and uncertainty about economic variables. Faust and Svensson (2001), Barro and Gordon (1983), and Geraats (2002), all using different economic indicators, show that more information is better because it reduces uncertainty about economic variables. The transparency of the central bank is vital not only for the ITF but for every monetary policy regime.

Dincer and Eichengreen (2006) have measured the transparency of 100 central banks, including that of Pakistan. They follow the definition of transparency proposed by Eijffinger and Geraats (2002) and take a large number of central banks as done by Fry, Julius, Mahadeva, and Roger (2000). They find that, "central banks in the advanced countries are more transparent than central banks in emerging markets (defined as middleincome countries with significant links to international financial markets), which in turn are more transparent than central banks in developing countries." The transparency of the SBP as measured by this approach is provided in Table 3 below.

Table 3: Transparency of SBP

\begin{tabular}{ccccccccc}
\hline & $\mathbf{1 9 9 8}$ & $\mathbf{1 9 9 9}$ & $\mathbf{2 0 0 0}$ & $\mathbf{2 0 0 1}$ & $\mathbf{2 0 0 2}$ & $\mathbf{2 0 0 3}$ & $\mathbf{2 0 0 4}$ & $\mathbf{2 0 0 5}$ \\
\hline Pakistan & 2.5 & 2.5 & 2.5 & 2.5 & 2.5 & 2.5 & 3.5 & 3.5 \\
\hline
\end{tabular}

Source: Dincer and Eichengreen (2006). 
Following Eijffinger and Geraats (2002), Malik and Din (2008) analyze monetary policy transparency in Pakistan. According to them, the SBP scores 4.5 out of 15 (where 15 is the highest) in transparency, as depicted in Figure 1 below.

Figure 1: Monetary policy transparency in Pakistan
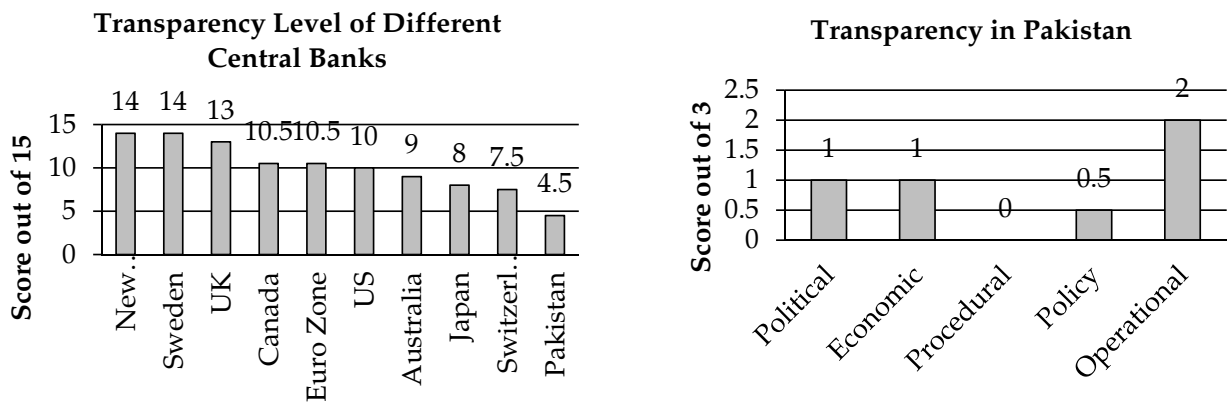

Source: Malik and Din (2008).

The SBP pursues multiple objectives with the dual mandate of price stability and output growth. It announces short-term targets but not medium-term objectives. Economic data on GDP and inflation is made available on a quarterly basis, but there is no information as to which macroeconomic model or rule is being used to forecast and establish short-term targets, nor is any comprehensive forecast made. Any policy change in instrument/tool is announced on the day of implementation, but no information or explanation is provided related to the change in operating target or the effect of that change on the intermediate target. There is no information on the institutional settings for interaction between the monetary and fiscal authorities, which is the prime reason for poor coordination between the government and the SBP. The SBP provides information on forecasting errors, but it does not explain how the forecasting was made or what contributed to those forecasting errors. Nor does it provide information on the exact contribution of the monetary policy to achieving its announced objectives; rather, it conducts a superficial and vague policy evaluation.

These facts show that the SBP's transparency level is fairly low, which is the major hindrance in implementing an ITF. Unless the central bank is transparent, its credibility will be low and it cannot anchor public expectations, as a result of which policy actions cannot be transmitted to the economy as desired. 


\subsubsection{Fiscal Discipline}

Another important prerequisite for the successful adoption of an ITF is the absence of a fiscal deficit, and sound coordination between fiscal and monetary authorities. According to Masson et al., 1997, fiscal dominance is one of the major obstacles in the implementation of inflation targeting.

Fiscal deficits are highly inflationary through their impact on the money supply. There is a vicious cycle between a fiscal deficit and inflation. A high deficit is financed by increasing the money supply; a high money supply causes high inflation; to curb this inflation, interest rates are raised, which not only crowds out investment, but also raises the deficit further by raising debt payments; the inflation indirectly impacts the fiscal deficit by reducing the real value of tax collection; and the cycle continues thus (Jha, 2005).

Pakistan's economy is characterized by high fiscal deficits. The budget deficit widened to 8.3 percent of GDP in the 12 months up to 30 June 2008 - the highest since 1991, when it had reached 8.8 percent of GDP, according to the finance ministry website. ${ }^{2}$ Monetary policy cannot effectively limit inflation in the presence of an expansionary fiscal policy and high government borrowing from the banking sector. Almost 60 percent of the budget deficit was financed by commercial banks and the SBP during the period 1 July to 29 January in the fiscal year $2008^{3}$ (SBP MPS of January-June 2008).

As shown by Khan and Qayyum (2007), inflation is affected by the government's bank borrowing for budgetary support and the fiscal deficit. "Our inflation is reaching alarming levels mainly due to borrowing," said the SBP's governor, Shamshad Akhtar, when announcing the monetary policy for the fiscal year 2008/09.

In this situation, even if the SBP were to adopt price stability as its primary objective, achieving this objective would depend on fiscal discipline in the economy. The SBP does not have the option of not financing the high fiscal deficit-if it were to decide to do so, the outcome would still be inflationary since the public debt/GDP ratio could become unsustainable in the medium term.

\footnotetext{
${ }^{2} \mathrm{http}$ //www.nation.com.pk/pakistan-news-newspaper-daily-english-online/Politics/30-Jul2008/Govt-borrowings-alarm-State-Bank

${ }^{3} \mathrm{http}: / /$ www.sbp.org.pk/m_policy/MPS-JAN-JUNE-FY08-EN.pdf
} 
Figure 2 clearly shows the higher fiscal deficit after 1990. The same pattern also occurs in domestic and foreign borrowing, although there seems to be a systematic switch between the two, which could be due to the government having used these two sources to redeem one another alternately. This situation is more likely keeping in view the fact that the main source of deficit financing in Pakistan is borrowing either from the banking sector or from foreign governments.

Figure 2: Fiscal deficit (FD), net domestic and foreign borrowings (NDB, NFB)



Pakistan has always been exposed to high fiscal deficits throughout its history, which have proved a major hindrance in the proper working of its monetary policy. The absence of this prerequisite is considered sufficient to reject the adoption of an ITF by emerging economies, and favors exchange rate targeting in these countries.

\subsubsection{Floating Exchange Rate}

Another important ITF prerequisite is a floating exchange rate regime. Pakistan followed a fixed-peg exchange rate regime up to the early 1980s, after which the monetary authorities decided to abandon it. As a result of this policy shift, the exchange rate regime evolved to "managedfloat" till 2000 and to "free floating" thereafter (Khan \& Qayyum, 2007). Although Pakistan claims to follow a floating exchange rate regime, an IMF report on the de facto exchange rate regimes of different countries ranks it as one of those countries with differently claimed (de jure) and actual (de facto) exchange rate policies. According to the report, Pakistan falls under the category of "other conventional fixed peg arrangement"4.

\footnotetext{
${ }^{4}$ http://www.imf.org/external/np/mfd/er/index.asp
} 
This inconsistency between the de jure and de facto actions of the monetary authorities and their reluctance to let the exchange rate float freely can be explained by the "fear-of-floating" literature (Calvo \& Reinhart, 2002), which argues that:

- Exchange rate vulnerability can severely affect an economy's balance sheet through the banking, corporate, or even public sectors if the economy has high liabilities denominated in foreign currency.

- Exchange rate vulnerability may be passed through to domestic price levels by its pass-through mechanism, which can be highly inflationary.

According to Husain (2006), apparent evidence of potential balance-sheet-type effects seems to suggest a case for pegging the rupee. However, there is little evidence of significantly higher pass-through of the exchange rate into domestic inflation in Pakistan than in other countries. Hyder and Shah (2004) come to the same point that the exchange rate passthrough effect on domestic inflation in Pakistan is quite weak.

\subsubsection{Sufficient Foreign Reserves}

On one hand, Pakistan's foreign reserves are decreasing due to its high trade deficit and debt servicing; on the other hand, the devaluation of the Pakistani rupee is increasing the burden of foreign borrowing and the trade deficit. Figure 3 shows the forex reserves held by the SBP and other banks in the form of SDR and USD.

Figure 3: International reserves of SDR and USD

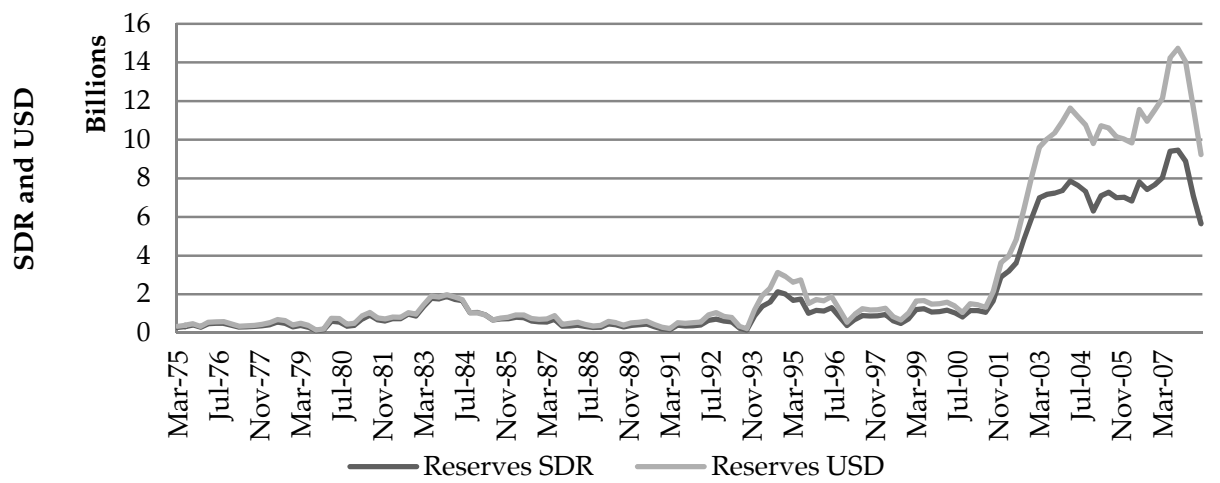

Figure 3 clearly indicates that the country's forex reserves were consistently low until 2000, after which a sharp increase is observed. The probable reason for this drastic increase is the high level of foreign 
remittances from all over the world to Pakistan after September 2011. This was also confirmed by the SBP while emphasizing additionally the contribution and rise in foreign direct investment (FDI). FDI rose by more than 69 percent to USD 2.1 billion in the first seven months of the fiscal year 2006/07 (July-June), led by inflows into the financial, communications, and energy sectors. However, Pakistan's foreign reserves, which hit a record high of USD 16.5 billion in October 2007, were depleted by high payments for oil imports and fell to USD 9.57 billion in the week ending on 16 August 2008 (Reuters, 22 August 2008).

Historically, Pakistan's foreign reserves have never been very high, although there had been a constant increase during 2000 to 2007. The even higher level of uncertainty since 2007 suggests that the country would probably not be able to maintain the sufficient (that is, higher) level of reserves required to successfully adopt an ITF.

\subsubsection{Demand-Side Dominance}

An implicit assumption of the ITF is that monetary policy should respond primarily to demand-side shocks since the recurrence of supply shocks limits the role of monetary policy in containing inflation. Pakistan is a small open economy that is highly dependent on imports and supply shocks such as increases in oil and commodity prices within and abroad, which makes inflation in Pakistan dependent on monetary as well as nonmonetary factors.

Chaudhry and Choudhary (2006) suggest that

Pakistan's economy is operating at a very horizontal portion of the supply curve and the major cause of inflation is an increase in import prices, not in the mismanagement of monetary policies.

They also find that

the growth rate of import prices is the most important determinant of inflation in Pakistan, both in the short run and long run, which is followed by growth rate of output.

\subsubsection{Financial System Strength}

The last but not least precondition for the adoption of an ITF is the strength of a country's financial system. A healthy financial system not 
only minimizes the potential conflicts that might arise between the economic stability objective and financial stability objective, but also guarantees the effective and smooth transmission of monetary policy. Financial stability is vital for the eventual success of any monetary policy; in the case of a fragile financial system, the central bank may become overly constrained whenever there is a need to increase the interest rate to tighten monetary policy since this increase could result in the contraction financial institutions' balance sheets. In addition, the more developed or sophisticated a country's financial system, the more a central bank is likely to emphasize inflation control and macroeconomic outlook.

According to the IMF's World Economic Outlook of October 2005, the strength of Pakistan's financial system is noteworthy. It is measured using different indicators, such as measures of financial market depth (private-bond-issuance-to-GDP, ratios of stock-market-capitalization-toGDP, stock market turnover or the maximum maturity of actively traded nominal bonds, and the extent of banks' foreign currency open positions) and risk-weighted capital adequacy ratio. Table 4 shows that Pakistan performs better than its peers and scored 0.5, which is equal to the average score of industrial countries.

Table 4: Comparative strength of financial systems

\begin{tabular}{lc}
\hline & Financial system health $^{\mathbf{5}}$ \\
\hline Average of industrial economies & 0.5 \\
Average of emerging economies & 0.4 \\
Pakistan & 0.5 \\
\hline
\end{tabular}

Source: Zaidi (2006).

An important factor behind this favorable result is the comprehensive financial sector reforms of the late 1980s, which resulted in a healthier and more competitive banking system (Zaidi, 2006).

\subsection{A Royal Flush or a Seven-Deuce Offsuit?}

In Table 5, we present a summary of the analysis above along with the status of each prerequisite based on the available information and judgments (which could of course be different from those of other researchers).

${ }^{5}$ IMF staff calculations, source: Zaidi (2006). 
Table 5: Summary of ITF 48prerequisites

\begin{tabular}{|c|c|c|}
\hline Prerequisite & Status & Comments \\
\hline $\begin{array}{l}\text { Independence } \\
\text { of SBP }\end{array}$ & Partial & $\begin{array}{l}\text { SBP has de jure independence but when it comes to } \\
\text { operationalizing monetary policy actions, it does } \\
\text { not have much political independence. }\end{array}$ \\
\hline $\begin{array}{l}\text { Transparency of } \\
\text { information }\end{array}$ & Partial & $\begin{array}{l}\text { SBP is partially transparent since it has started to } \\
\text { provide some information on economic state but } \\
\text { does not provide information on ex ante or } \\
\text { proactive basis that is required for pre- } \\
\text { commitment to inflation target. }\end{array}$ \\
\hline Fiscal discipline & No & $\begin{array}{l}\text { This condition is not met at all. There is no } \\
\text { coordination between fiscal and monetary } \\
\text { authorities and fiscal gap has always been negative. }\end{array}$ \\
\hline $\begin{array}{l}\text { Floating } \\
\text { exchange rate }\end{array}$ & No & $\begin{array}{l}\text { Although SBP claims that it has adopted floating } \\
\text { exchange rate regime, de facto regime of Pakistan is } \\
\text { pegged exchange rate as indicated by IMF. }\end{array}$ \\
\hline $\begin{array}{l}\text { Moderate or } \\
\text { low debt level }\end{array}$ & No & $\begin{array}{l}\text { Government borrowing is increasing and this } \\
\text { problem has become more severe in the last decade. }\end{array}$ \\
\hline $\begin{array}{l}\text { Sufficient } \\
\text { foreign reserves }\end{array}$ & $\begin{array}{c}\text { No (at } \\
\text { least } \\
\text { presently) }\end{array}$ & $\begin{array}{l}\text { The reserves condition has always been } \\
\text { dissatisfactory in Pakistan except for the period } \\
\text { 2000-07. The present data also indicates a } \\
\text { downward trend in reserves. }\end{array}$ \\
\hline $\begin{array}{l}\text { Dema } \\
\text { domi }\end{array}$ & No & $\begin{array}{l}\text { Pakistan's economy is characterized by supply- } \\
\text { side shocks and is heavily dependent on imports } \\
\text { and oil prices. }\end{array}$ \\
\hline $\begin{array}{l}\text { Financial system } \\
\text { strength }\end{array}$ & Yes & $\begin{array}{l}\text { Pakistan's economy is bank-based as opposed to } \\
\text { market-based. Although the reforms of the } 1990 \mathrm{~s} \\
\text { have strengthened the banking sector, there is still a } \\
\text { need for more maturity and depth since the sector } \\
\text { boom could be the result of a credit bubble. }\end{array}$ \\
\hline
\end{tabular}

All the indicators and prerequisites lead to reservations about the prospects of adopting an ITF in Pakistan. Inflation targeting requires that central banks refrain from using any other nominal anchor, but all the indicators in Pakistan suggest that inflation targeting cannot be the SBP's sole objective. The SBP cannot ignore the issue of a fiscal deficit, high government borrowing, currently falling reserves, large swings in the exchange rate, the depreciating rupee, and supply-side shocks due to high increases in consumer and oil prices. All these issues require the SBP's prime attention, thus hampering its commitment toward the single nominal anchor of inflation and metaphorically putting it in the situation of having the worst possible hand in a poker game, or a "seven-deuce offsuit". 


\section{Econometric Assessment}

An implicit condition of pursuing an ITF is that there should be a stable and significant relationship between the measure of inflation to be controlled and the short-term interest rate. The short-term interest rate is the major tool used by central banks to transmit monetary policy, and low/stable inflation is their final objective. The interest rate can influence inflation through the cost-of-capital channel, the exchange rate channel, and the wealth effect channel. Here, however, we are interested only in the causality of the short-term interest rate with reference to the inflation measure rather than in a particular transmission channel because this causality is important in the subsequent success of an ITF.

\subsection{Data, Methodology, and Results}

The essence of an ITF is that the interest rate should be used to correct the deviation of actual inflation from the target. By using the Granger causality test, we investigate whether the interest rate Grangercauses the inflation measure in Pakistan. Equation (1) below expresses the general form of this causality:

$$
y_{t}=\alpha_{0}+\alpha_{1} y_{t-1}+\ldots+\alpha_{n} y_{t-n}+\beta_{1} x_{t-1}+\ldots+\beta_{n} x_{t-n}+\varepsilon_{t}
$$

Since the Granger causality test is relevant only when the variables involved are either stationary or nonstationary but co-integrated, the methodology of our empirical work is as follows:

- Tests for stationarity

- Tests for co-integration: Engle-Granger approach

- Tests for co-integration: Johansen and Juselius approach

- Granger-causality test

We use quarterly data from 1976 to 2007 from the International Financial Statistics database. The reason for dropping data from before this period is the separation of East Pakistan and other major political disturbances in 1971 that caused major shifts in the economy and financial structure, and due to which the economy remained turbulent up to 1975. The variables used in this analysis are as follows:

- $\quad I N F=$ inflation based on CPI of 12 major cities

(base $=2000)$ 
- $\quad P R=$ policy rate (discount rate used by SBP as a primary monetary tool)

- $X R G=$ exchange rate growth (appreciation/depreciation of PKR/USD, period average)

- $M 1 G=$ growth rate of narrow money

Choosing between core and headline inflation to represent inflation is critical when analyzing inflation dynamics. It is an established fact that headline inflation is far more volatile than core inflation because of the high representation of commodities and oil, and thus policymakers should focus only on core inflation, which is much more stable, when designing monetary policy (Mishkin, 2007). However, it can also be argued that core inflation is not a true representation of inflation in any economy and that, being already very stable, there is no need to worry about it. Policymakers in less developed economies such as Pakistan, where the share of oil and food prices in individual consumption budgets is very high, should do their best to curtail headline inflation (CPI), which is a threat to growth. There is strong evidence in favor of using the CPI rather than core inflation-recent studies suggest that food and energy prices are not the most volatile components of inflation and that core inflation is not always the best predictor of total inflation (Novak, Crone, Mester, \& Khettry, 2008).

The major advantage of using quarterly data is its additional relevance and usability in the context of less developed countries as observed by Ryan and Milne (1994). We calculate the quarterly growth rates of CPI-12 major cities, the exchange rate (PKR/USD), and M1 (narrow money) on an annual basis by taking the fourth lagged difference of their natural logarithms. In other words, we calculate the annual percentage change in the concerned variable with their values from the corresponding quarter in the previous year.

This percentage change will serve as INF, XRG, and $M 1 G$, respectively, where INF is the principal variable of interest and $P R, X R G$, and M1G will act as the anchors of inflation targeting, exchange rate targeting, and monetary aggregate targeting, respectively. The relationship of each anchor with the ultimate objective of low inflation is estimated in the next section. 


\subsection{Test for Stationarity}

The Phillips-Perron (PP) test for non-stationarity is applied to all the variables. Table 6 below shows that we can reject the null of the unit root at a 1 percent level of significance only in the case of the M1 growth rate. For level inflation, the PP statistics suggest stationarity (only at a 10 percent significance level), which is more logical to assume for inflation. However, the augmented Dickey-Fuller (ADF) statistics suggest the presence of a unit root (nonstationarity), which is consistent with several previous studies on Pakistan and thus reduces the authenticity of the conclusion drawn on the basis of the PP statistics. All the other variables are found to have a unit root, i.e., they are nonstationary. However the first differences of all the variables are stationary at 5 percent or a low level of significance.

Table 6: Results of tests for stationarity of variables

\begin{tabular}{lllcll}
\hline Variables & PP statistics & \multicolumn{1}{c}{$\begin{array}{c}\text { ADF } \\
\text { statistics }\end{array}$} & Variables & PP statistics & $\begin{array}{c}\text { ADF } \\
\text { statistics }\end{array}$ \\
\hline INF & $-2.765^{*}$ & -2.099 & $\Delta \mathrm{INF}$ & $-9.15^{* * *}$ & $-8.05^{* * *}$ \\
PR & -1.75 & -1.51 & $\Delta \mathrm{PR}$ & $-9.94^{* * *}$ & $-9.88^{* * *}$ \\
XRG & -2.57 & -2.52 & $\Delta \mathrm{XRG}$ & $-9.46^{* * *}$ & $-9.995^{* * *}$ \\
M1G & $-5.43^{* * *}$ & $-3.14^{* *}$ & $\Delta \mathrm{MIG}$ & $-25.87^{* * *}$ & $-10.098^{* * *}$ \\
\hline
\end{tabular}

Note: ${ }^{* * *}, * *$, and ${ }^{*}$ respectively indicate rejection of the null at $1 \%, 5 \%$, and $10 \%$ significance levels.

\subsection{Test for Co-Integration}

Although the real purpose of any econometric model is to develop a relationship between a set of economic variables, this relationship could be spurious if the variables are nonstationary. The PP test above indicates that all the variables apart from $M 1 G$ are stationary at first difference. In this scenario, a meaningful relationship can only be established between the variables if they are co-integrated (Engle \& Granger, 1987).

To identify the co-integration relationship between INF and the other variables $(P R, X R G$, and $M 1 G)$, we first use the Engle-Granger approach. Co-integration is checked by running a regression of variables and then by applying a stationarity test to its residuals. If the residuals are found to be stationary, it indicates that the variables are co-integrated and there exists a long-run relationship. The estimated bivariate regressions are represented by Equations (2), (3), and (4), where the dependent variable INF is the same and the independent variable is one 
of the three anchors $(P R, X R G, M 1 G)$, each representing three different monetary policy regimes. We also introduce a multivariate regression (equation 5) containing all three anchors simultaneously.

$$
\begin{aligned}
& I N F=c+\alpha P R+\varepsilon \\
& I N F=c+\alpha X R G+\varepsilon \\
& I N F=c+\alpha M 1 G+\varepsilon \\
& I N F=c+\alpha_{1} P R+\alpha_{2} X R G+\alpha_{3} M 1 G+\varepsilon
\end{aligned}
$$

\begin{tabular}{|c|c|c|c|c|}
\hline Variables & Coefficient & Standard error & Test statistic & Prob. \\
\hline \multicolumn{5}{|c|}{ INF and $P R$} \\
\hline $\mathrm{c}$ & $4.21^{* * *}$ & 1.02 & 4.12 & 0.0001 \\
\hline PR & $0.29^{* * *}$ & 0.09 & 3.25 & 0.0015 \\
\hline \multicolumn{3}{|c|}{ PP test applied to residuals of Equation 2} & $-2.89^{* *}$ & 0.0493 \\
\hline \multicolumn{5}{|c|}{ INF and XRG } \\
\hline c & $7.61^{* * *}$ & 0.37 & 20.68 & 0.0000 \\
\hline XRG & -0.03 & 0.04 & -0.75 & 0.4569 \\
\hline \multicolumn{3}{|c|}{ PP test applied to residuals of Equation 3} & $-2.75^{*}$ & 0.0686 \\
\hline \multicolumn{5}{|c|}{ INF and M1G } \\
\hline c & $7.07^{* * *}$ & 0.75 & 9.44 & 0.0000 \\
\hline M1G & 0.025 & 0.05 & 0.50 & 0.6161 \\
\hline \multicolumn{3}{|c|}{ PP test applied to residuals of Equation 4} & $-2.78^{*}$ & 0.0643 \\
\hline
\end{tabular}

The results of the three regressions are summarized in Table 7 below, revealing the following observations:

Table 7: Results of bivariate regressions

Note: ${ }^{* * *},{ }^{* *}$, and ${ }^{*}$ respectively indicate rejection of the null at $1 \%, 5 \%$, and $10 \%$ significance levels.

- INF and PR are co-integrated of order one because we can reject the null hypothesis of the unit root for the residuals of equation (2) at less than a 5 percent level of significance. The coefficient of $P R$ in the cointegration vector is, however, significant but has a positive sign. This contradicts theoretical and historical expectations, thus suggesting that $P R$ does not have the ability to affect INF in the same way as monetary authorities intend. 
- The PP test when applied to the residuals of equation (3) shows that we cannot reject the existence of co-integration between INF and XRG at a 10 percent level of significance. However, the negative sign of $X R G$ in equation (3) indicates that positive growth (the depreciation of PKR against USD) helps reduce inflation, which is surprisingly contrary to expectations as already observed in the case of the relationship between INF and PR.

- There is a possibility that INF and M1G are also co-integrated since the null of the unit root is rejected at a 10 percent significance level. Again, however, the coefficient of M1G, despite being positive, is insignificant, thus showing its inability to play any meaningful role in containing inflation in the long run.

Table 8: Results of multivariate regression

\begin{tabular}{lllll}
\hline Variables & Coefficient & Standard error & Test statistic & Prob. (P-val.) \\
\hline C & 1.71 & 1.53 & 1.12 & 0.2661 \\
PR & $0.45^{* * *}$ & 0.10 & 4.45 & 0.0000 \\
XRG & $-0.098^{* *}$ & 0.05 & -2.18 & 0.0309 \\
M1G & $0.09^{*}$ & 0.05 & 1.74 & 0.0847 \\
Tests for nonstationarity on residuals of Equation 5 & \\
\multicolumn{2}{l}{ Phillips-Perron test } & $-3.14^{* *}$ & 0.0264 \\
\hline
\end{tabular}

Note: ${ }^{* *}, * *$, and ${ }^{*}$ respectively indicate rejection of the null at $1 \%, 5 \%$, and $10 \%$ significance levels.

The results of the multivariate regression estimated in equation (5) (Table 8 above), demonstrate that there is evidence of significant long-run co-integration among the variables since the residuals are stationary at an almost 2 percent level of significance according to the PP test. All the coefficients are significant at 10 percent or below, but the positive sign of the PR as opposed to the expected negative sign still questions its importance when formulating policy decisions regarding inflation.

\subsection{Test for Co-Integration (Johansen and Juselius Approach)}

Given the shortcomings of the Engle-Granger approach when more than one co-integration relationship exists, we extend our analysis to the use of the vector autoregression (VAR)-based co-integration test following the framework and methodology developed by Johansen and Juselius (1990) and Johansen (1991). 
Consider a VAR of order $\mathrm{p}$ :

$$
y_{t}=A_{1} y_{t-1}+\cdots+A_{p} y_{t-p}+B x_{t}+\epsilon_{t}
$$

where $y_{t}$ is a k-vector of nonstationary I(1) variables, $x_{t}$ is a d-vector of deterministic variables, and $\epsilon_{t}$ is a vector of innovations. This VAR could be rewritten as

$$
\Delta y_{t}=\prod y_{t-1}+\sum_{i=1}^{p-1} \Gamma_{i} \Delta y_{t-i}+B x_{t}+\epsilon_{t}
$$

where $\Pi=\sum_{i=1}^{p-1} A_{i}-I, \quad \Gamma_{i}=-\sum_{j=i+1}^{p} A_{j}$

We use two different specifications of Johansen's test, one with an intercept and one with both an intercept and trend term, in co-integrating equations (results not reported here), simultaneously allowing for a linear deterministic trend in the data for both specifications. The difference in specifications does not change our results.

The trace statistics and maximum eigenvalue statistics calculated according to equations (8) and (9) are reported in Table 9:

$$
\begin{aligned}
& L R_{t r}(r \mid k)=-T \sum_{i=r+1}^{k} \log \left(1-\lambda_{i}\right) \\
& L R_{\text {max }}(r \mid r+1)=-T \log \left(1-\lambda_{r+1}\right)=L R_{t r}(r \mid k)-L R_{t r}(r+1 \mid k)
\end{aligned}
$$

\begin{tabular}{|c|c|c|c|c|c|}
\hline \multirow{2}{*}{$\begin{array}{l}\text { Hypothesized } \\
\text { no. of CE(s) }\end{array}$} & \multirow{2}{*}{ Eigenvalue } & \multicolumn{2}{|c|}{ Trace statistic } & \multicolumn{2}{|c|}{ Max. eigen statistic } \\
\hline & & $\lambda_{\text {trace }}$ & Prob.** & $\lambda_{\max }$ & Prob. ${ }^{* *}$ \\
\hline None* & 0.27 & 82.5 & 0.0000 & 37.98 & 0.0016 \\
\hline At most $1^{*}$ & 0.17 & 44.53 & 0.0005 & 22.71 & 0.0298 \\
\hline At most $2 *$ & 0.14 & 21.82 & 0.0049 & 18.23 & 0.0112 \\
\hline At most 3 & 0.03 & 3.596 & 0.0579 & 3.596 & 0.0579 \\
\hline
\end{tabular}

Table 9: Trace statistics and maximum eigenvalue statistics

Table 9 indicates that, according to both the trace and maximum statistics, the null of no co-integrating relationship is rejected and we can proceed in accepting two co-integrated relationships at a 5 percent level of significance. The normalized co-integrated coefficients provided by Johansen's test are reported in Table 10 below. 
Table 10: Normalized co-integrated coefficients

\begin{tabular}{llc}
\hline Variables & Coefficient & Standard error \\
\hline PR & 0.43 & 0.29 \\
XRG & $0.58^{* * *}$ & 0.15 \\
M1G & $0.99^{* * *}$ & 0.19 \\
\hline
\end{tabular}

The results above are consistent with the Engle-Granger approach as far as the sign of PR is concerned, thus confirming the long-run "positive" relationship between the PR and inflation. This conclusion reinforces our argument that the PR cannot be used as a suitable anchor to target inflation in the long run, which is explicitly required by the ITF. The positive signs and significant values of the coefficients XRG and M1G support not only the present practice of monetary aggregate targeting by the SBP, but also indicate that exchange rate targeting could be another viable solution to stabilizing inflation, as believed by many researchers.

\subsection{Granger-Causality Test}

An ITF requires that, whenever inflation deviates from its target, we must use the interest rate to correct it. The interest rate can influence inflation and its behavior only if it is able to Granger-cause inflation. The results of the Granger-causality tests for INF and PR are given in Table 11. The maximum lag length is six. This is because the frequency of data is quarterly and six lags allow us to look sufficiently for the impact of the policy anchor on inflation.

Table 11: Results of the Granger-causality tests for INF and PR

\begin{tabular}{lllllll}
\hline & \multicolumn{2}{c}{ PR and INF } & \multicolumn{2}{c}{ M1G and INF } & \multicolumn{2}{c}{ XRG and INF } \\
\cline { 2 - 7 } Lags & PR does not & \multicolumn{2}{c}{ INF does not MIG does not INF does not XRG does not } & INF does no \\
& cause INF & cause PR & cause INF & cause MIG & cause INF & cause XRG \\
\hline 1 & 0.88797 & $10.2621^{* * *}$ & $3.55603^{*}$ & 0.34824 & 1.83792 & $4.06033^{* *}$ \\
2 & 1.48705 & $3.78914^{* *}$ & $2.69644^{*}$ & 0.39464 & 1.79348 & 1.97912 \\
3 & 0.79772 & $2.91086^{* *}$ & 1.84064 & 0.55833 & 0.99323 & 1.42825 \\
4 & 0.91607 & 1.92303 & 1.72427 & 0.45566 & 0.97093 & 1.23869 \\
5 & 1.28657 & 1.41905 & $3.04773^{* *}$ & 0.95606 & 1.61360 & 1.08389 \\
6 & 0.93968 & 1.24934 & $2.48110^{* *}$ & 0.84166 & 1.28282 & 0.88718 \\
\hline
\end{tabular}

Note: ${ }^{* * *}, * *$, and ${ }^{*}$ respectively indicates rejection of the null at $1 \%, 5 \%$, and $10 \%$ significance levels.

The results lead us to infer that the interest rate and exchange rate are not particularly effective in influencing the behavior of inflation, and instead, that PR and XRG are caused by INF. However, we can say that 
M1G is able to affect INF up to six lags, which is somewhat consistent with Khalid (2005) who found that M1 Granger-causes INF at the third lag.

Since PR does not seem to affect inflation directly even up to six lags, we analyze further what PR is capable of influencing. We check the direction of causality of PR to M1G and PR to XRG. The results in Table 12 clearly indicate that the interest rate has an impact on narrow money, thus showing its importance in overall monetary policy by influencing inflation indirectly through money supply (Table 11).

Table 12: Direction of causality of PR to M1G and PR to XRG

\begin{tabular}{llccc}
\hline Lags & \multicolumn{2}{c}{ PR and M1G } & \multicolumn{2}{c}{ PR and XRG } \\
\cline { 2 - 5 } & $\begin{array}{c}\text { MIG does not } \\
\text { cause } P R\end{array}$ & $\begin{array}{c}P R \text { does not } \\
\text { cause } M I G\end{array}$ & $\begin{array}{c}\text { XRG does not } \\
\text { cause } P R\end{array}$ & $\begin{array}{c}\text { PR does not } \\
\text { cause } X R G\end{array}$ \\
\hline 1 & 0.09594 & $5.07934^{* *}$ & 0.50034 & 1.17508 \\
2 & 0.33712 & $2.92512^{*}$ & 0.51479 & $4.18419^{* *}$ \\
3 & 0.50003 & $3.85172^{* *}$ & 0.94424 & $4.11643^{* * *}$ \\
4 & 0.96001 & $5.49555^{* * *}$ & 1.79100 & $2.96494^{* *}$ \\
5 & $3.02597^{* *}$ & $3.35722^{* * *}$ & $3.55624^{* * *}$ & 1.00611 \\
6 & $3.17425^{* * *}$ & $3.02668^{* * *}$ & $3.09913^{* * *}$ & 0.62778 \\
\hline
\end{tabular}

Note: ${ }^{* * *},{ }^{* *}$, and ${ }^{*}$ respectively indicates rejection of the null at $1 \%, 5 \%$, and $10 \%$ significance levels.

It is also useful to highlight two interesting results yielded by the Granger causality test about the relationship between INF and XRG (Table 11) and between PR and XRG (Table 12). These results ${ }^{6}$ indicate that the interest rate not only affects the exchange rate directly, but also indirectly through the channel of money supply and inflation. All these relationships are explained clearly in Figure 4.

\footnotetext{
${ }^{6}$ These conclusions are robust to VAR analysis, the results of which are not reported here and can be obtained on request from the authors.
} 


\section{Figure 4: Observed monetary policy transmission channel in Pakistan}



Although our analysis is subject to certain limitations, we can interpret our results in line with Alvarez, Lucas, and Weber (2001), who are of the view that, "in the theory of inflation, consistent with much of the evidence, interest rates play no role whatsoever".

This rule seems to apply to Pakistan, and if Pakistan were to adopt an ITF, then inflation would not be sensitive to movements in the interest rate directly. We can also interpret these results in the manner that the "Granger Causality test provides support for using interest rate as an instrument to influence money supply, that subsequently Granger Cause inflation."

\section{Conclusion}

Success in poker depends significantly on the ranking of the hand (combination of cards) with which a participant starts. The odds in favor of success or a reasonable performance are very low with a seven-deuce offsuit, which is unanimously considered the worst possible hand in this game. We fear that, metaphorically, Pakistan also has a seven-deuce offsuit when applied to the decision whether to opt for an ITF.

In this paper, we have qualitatively assessed whether an ITF is applicable to Pakistan by evaluating its economy on the basis of various necessary economic and institutional structures required to successfully adopt such a framework. Our analysis shows that most of the 
preconditions of an ITF are either weak or nonexistent, which suggests that inflation cannot be the SBP's sole objective. The central banks cannot ignore the issues of fiscal deficit, high government borrowing, the current situation of falling reserves, large swings in the exchange rate, the depreciating rupee, and supply-side shocks.

We have also quantitatively assessed the significance and role of the short-term interest rate in the monetary policy transmission mechanism, and concluded that the former plays no role in affecting inflation directly in Pakistan. However, it can impact inflation through the money supply channel. The absence of a direct link between the interest rate and inflation is contrary to the essence of an ITF, which requires that the interest rate remain the sole anchor in targeting inflation.

These findings compel us to infer that Pakistan is not ready to adopt inflation targeting-even if the SBP were to decide to adopt itgiven the absence of the framework's preconditions, and the economy's inability to control inflation directly through the interest rate measure, which is the basic premise of an ITF. 


\section{References}

Alvarez, F., Lucas, R. E., Jr., \& Weber, W. E. (2001). Interest rates and inflation. American Economic Review, 91(2), 219-225.

Arnone, M., Laurens, B. J., Segalotto, J.-F., \& Sommer, M. (2007). Central bank autonomy: Lessons from global trends (Working Paper No. 07/88). Washington, DC: International Monetary Fund.

Barro, R. J., \& Gordon, D. B. (1983). Rules, discretion, and reputation in a model of monetary policy. Journal of Monetary Economics, 12(1), 101-122.

Bernanke, B. S., Laubach, T., Mishkin, F. S., \& Posen, A. S. (1999). Inflation targeting: Lessons from the international experience. Princeton, NJ: Princeton University Press.

Bruno, M., \& Easterly, W. (1998). Inflation crises and long-run growth. Journal of Monetary Economics, 41(1), 3-26.

Calvo, G. A., \& Reinhart, C. M. (2002). Fear of floating. Quarterly Journal of Economics, 107(2), 379-408.

Chaudhry, M. A., \& Choudhary, M. A. (2006). Why the State Bank of Pakistan should not adopt inflation targeting. State Bank of Pakistan Research Bulletin, 2(1), 196-209.

Dincer, N., \& Eichengreen, B. (2006, November). Central bank transparency: Where, why, and to what effect? Paper presented at the Conference on Central Banks as Economic Institutions, Cournot Center for Economic Studies, Paris, France.

Eijffinger, S., \& Geraats, P. (2002). How transparent are central banks? (Discussion Paper No. 3188). London, UK: Centre for Economic Policy Research.

Engle, R. F., \& Granger, C. W. (1987). Co-integration and error correction: Representation, estimation and testing. Econometrica, 55, 251-276. 
Faust, J., \& Svensson, L. (2001). Transparency and credibility: Monetary policy with unobservable goals. International Economic Review, 42, 369-397.

Fischer, S. (1993). The role of macroeconomic factors in growth. Journal of Monetary Economics, 32(3), 485-512.

Fry, M., Julius, D., Mahadeva, L., \& Roger, S. (2000). Key issues in the choice of a monetary policy framework. In L. Mahadeva \& G. Sterne (Eds.). Monetary policy frameworks in a global context. London, UK: Routledge.

Geraats, P. M. (2002). Central bank transparency. Economic Journal, 112, 532-565.

Geraats, P. M. (2005). Transparency of monetary policy: Theory and practice (Mimeo). Retrieved from http://www.econ.cam.ac.uk/faculty/geraats/tpmptp.pdf

Husain, A. M. (2006). Choosing the right exchange rate regime for Pakistan. State Bank of Pakistan Research Bulletin, 2(1), 92-111.

Hyder, Z., \& Shah, S. (2004, June). Exchange rate pass-through to domestic prices in Pakistan (Working Paper No. 5). Karachi, Pakistan: State Bank of Pakistan.

Jha, R. (2005). Inflation targeting in India: Issues and prospects (Working Paper No. 2005-04). Canberra: National University of Australia, Australia South Asia Research Centre.

Johansen, S. (1991). Estimation and hypothesis testing of cointegration vectors in Gaussian vector autoregressive models. Econometrica, $59,1551-1580$.

Johansen, S., \& Juselius, K. (1990). Maximum likelihood estimation and inferences on cointegration-with applications to the demand for money. Oxford Bulletin of Economics and Statistics, 52, 169-210. 
Judson, R., \& Orphanides, A. (1996). Inflation, volatility and growth (Finance and Economics Discussion Series No. 96-19). Washington, DC: Board of Governors of the Federal Reserve System.

Khalid, A. M. (2005). Economic growth, inflation, and monetary policy in Pakistan: Preliminary empirical estimates. Pakistan Development Review, 44(4, Pt. II), 961-974.

Khan, M. A., \& Qayyum, A. (2007). Exchange rate determination in Pakistan: Evidence based on purchasing power parity theory. Pakistan Economic and Social Review, 45(2), 181-202.

Kydland, F. E., \& Prescott, E. C. (1977). Rules rather than discretion: The inconsistency of optimal plans. Journal of Political Economy, 85 (June), 473-492.

Malik, W. S. (2007). Monetary policy objectives in Pakistan: An empirical investigation (Working Paper No. 2007:35). Islamabad: Pakistan Institute of Development Economics.

Malik, W. S., \& Din, M. (2008). Monetary policy transparency in Pakistan: An independent analysis (Working Paper No. 2008:44). Islamabad: Pakistan Institute of Development Economics.

Masson, P. R., Savastano, M. A., \& Sharma, S. (1998, March). Can inflation targeting be a framework for monetary policy in developing countries? Finance and Development, 35(1), 34-37.

Masson, P. R., Savastano, M. A., \& Sharma, S. (1997). The scope for inflation targeting in developing countries (Working Paper No. 97/130). Washington, DC: International Monetary Fund.

Mishkin, F. S. (2000). Inflation targeting in emerging market countries (Working Paper No. 7618). Cambridge, MA: National Bureau of Economic Research. 
Novak, J., Crone, T. M., Mester, L. J., \& Khettry, N. N. K. (2008). Core measures of inflation as predictors of total inflation (Working Paper No. 08-9). Philadelphia, PA: Federal Reserve Bank of Philadelphia.

Ryan, T. C. I., \& Milne, W. J. (1994). Analyzing inflation in developing countries: An econometric study with application to Kenya. Journal of Development Studies, 31(1), 134-156.

Taylor, J. B. (2000). Low inflation, pass-through and the pricing power of firms. European Economic Review, 44, 1389-1408.

Zaidi, I. M. (2006). Exchange rate flexibility and the monetary policy framework in Pakistan. State Bank of Pakistan Research Bulletin, 2(1), $115-138$. 